\title{
Antibacterial activity of tannins from the leaves of Solanum trilobatum Linn.
}

\author{
A. Doss, $\mathrm{H}$. Mohammed Mubarack and R. Dhanabalan \\ Department of Microbiology, RVS College of Arts and Science, Coimbatore, Tamilnadu, India. \\ dossandro@gmail.com
}

Abstract: Compounds of pharmacological interest (tannins) were isolated from the plant species, Solanum trilobatum Linn and assayed against the bacteria, Staphylococcus aureus, Streptococcus pyrogens, Salmonella typhi, Pseudomonas aeruginosa, Proteus vulgaris and Escherichia coli using agar diffusion method. Tannins exhibited antibacterial activities against all the tested microorganisms. S.aureus was the most resistant to tannins isolated from the plant material followed by Streptococcus pyrogens, Salmonella typhi, Escherichia coli, Proteus vulgari and Pseudomonas aeruginosa. Minimum inhibitory concentration of the tannins ranged between 1.0 and $2.0 \mathrm{mg} / \mathrm{ml}$ while the minimum bactericidal concentration ranged between 1.5 and $2.0 \mathrm{mg} / \mathrm{ml}$.

Keywords: Solanum trilobatum, tannins, methanol, bacterial pathogens, minimum inhibitory concentration, minimum bactericidal concentration

Introduction

Tannins are polyphenols that are obtained from various parts of different plants (Gajendiran \& Mahadevan, 1990). In addition to use in leather processing industries, tannins have shown potential antiviral (Lin et al, 2004), antibacterial (Akiyama et al., 2001; Funatogawa et al., 2004), and antiparasitic effects (Bhagavathi et al, 1999; Yang et al, 2000; Tanimura et al, 2005). In the past few years tannins have also been studied for their effects against cancer through different mechanisms.

Solanum trilobatum Linn. (Solanaceae-herbs) is an important medicinal plant. It contains rich amount of calcium, iron, phosphorus, carbohydrates, fat, crude fibre and minerals in the leaves (Jawahar et al., 2004). It is used to cure asthma, arrest blood vomiting, to reduce blood glucose level and bilious matter phlegmatic rheumatism and several kinds of leprosy. It is also antibacterial, antifungal, antimitotic, antioxidant and antimtumours (Purushothaman et al., 1969; Shahjahan et al., 2004; Shahjahan et al., 2005). This study was carried out to evaluate the antibacterial properties of tannins isolated from S.trilobatum.

Materials and methods

Source of plant material

The leaves of the plant were collected from Western Ghats, Tamilnadu and the species was duly authenticated at Botanical Survey of India (Southern Circle), Coimbatore Tamilnadu.

Microorganisms

Clinical isolates of the bacteria viz., Staphylococcus aureus, Streptococcus pyrogens, Salmonella typhi, Pseudomonas aeruginosa Proteus vulgaris and Escherichia coli used in this study were obtained from Microbial Diagnostic Laboratory, RVS Hospital, Coimbatore, Tamilnadu.

\section{Preparation of plant extract}

Methanolic extract of the leaf of the plant was prepared according to the method described by Okogun (2000).

\section{Extraction of tannins}

Sample of the powdered leaf $(3 \mathrm{~g})$ was boiled in 5 $\mathrm{ml}$ of distilled water for $3 \mathrm{~min}$ on a hot plate. The mixture was filtered while hot and the resulting filtrate was used to carry out ferric chloride test. (Trease \& Evans, 1983). Sample of the filtrate $(1.0 \mathrm{~g})$ was transformed into a beaker and $10 \mathrm{ml}$ of distilled water was added. This was boiled for $5 \mathrm{~min}$. Two drops of $5 \%$ ferric chloride $(\mathrm{FeCl} 2)$ was then added. Production of greenish precipitate indicated the presence of tannins (Trease \& Evans, 1983).

Antimicrobial test

The antibacterial test was performed by following agar disc diffusion method (Bauer \& Kirby, 1996; Salie et al., 1996; Perez et al., 1990; Nair \& Chanda, 2005) using Mueller Hinton Agar No. 2 medium for the assay. Microbial growth was determined by measuring the diameter of the zone of inhibition (SD \pm Mean).

Determination of Minimum Inhibitory Concentration

Various concentrations of tannins from the plant, Solanum trilobatum ranging between 4.0 and 6.0 $\mathrm{mg} / \mathrm{ml}$ were introduced into different test tubes; each tube was inoculated with an overnight culture of Staphylococcus aureus, Proteus vulgaris, Streptococcus pyrogens, Escherichia coli, Salmonella typhi and Pseudomonas aeruginosa diluted to give a final concentration of 106 cells per $\mathrm{ml}$. The tubes were incubated at $37^{\circ} \mathrm{C}$ for $24 \mathrm{~h}$. The least concentration of tannin that did not permit any visible growth of the inoculated test organism in broth culture was regarded as the minimum inhibitory concentration (MIC) in each case (Collins et al., 1995).

\section{Determination of Minimum Bactericidal Concentration}

After culturing the test organisms separately in nutrient broth containing various concentrations of the active ingredients, the broth was inoculated onto freshly prepared agar plates to assay for the bactericidal effect. The culture was incubated at $37^{\circ} \mathrm{C}$ for $24 \mathrm{~h}$. The lowest concentration of alkaloid that does not yield any colony growth on the solid medium after the incubation period was regarded as minimum bactericidal concentration (MBC) (Alade \& Irobi, 1995). 


\section{Results and discussion}

The presence of antibacterial substances in the higher plants is well established (Srinivasan et al., 2001). Plants have provided a source of inspiration for

novel drug compounds as plants derived medicines have made significant contribution towards human health. Phytomedicine can be used for the treatment of diseases as is done in case of Unani and Ayurvedic system of medicines or it can be the base for the development of a medicine, a natural blueprint for the development of a drug (Jigna Parekh \& Sumitra Chanda, 2007)

The sensitivity of seven pathogenic bacteria to the tannins of the leaves of Solanum trilobatum was tested and compared to that of antibacterial antibiotic Streptomycin. The results pointed out that these tannins possessed the highest antibacterial activity against the bacteria, Staphylococcus aureus and Proteus vulgaris at $2.5 \mathrm{mg} / \mathrm{ml}$ concentration (Table.1), whereas they were moderately active against the remaining bacteria. Several plants which are rich in tannins have been shown to possess antimicrobial activities against a number of microorganisms. For example Banso and Adeyemo (2007) investigated the antibacterial activity of leaf extract Dichrostachys cinerea and reported that tannins, alkaloids and glycosides were detected. Amongst the gram-positive and gram-negative bacteria, gram-positive bacterial strains were more susceptible to the extracts when compared to gram negative bacteria. This may be attributed to the fact that these two groups differ by its cell wall component and its thickness (Yao et al., 1995). The ability of tannin compounds to cause the bacterial colonies to disintegrate probably results from their interference with the bacterial cell wall; thereby inhibiting the microbial growth (Erasto et al., 2004; Viljoen et al., 2003).

The MIC of tannins isolated in this study against the test organisms ranged between 1.0 and $4.0 \mathrm{mg} / \mathrm{ml}$ while the MBC ranged between 1.5 and $4.5 \mathrm{mg} / \mathrm{ml}$ (Table 2). Antimicrobial agents with low activity against an organism had a high MIC while a highly active antimicrobial agent gave a low MIC. The antibacterial effectiveness with the increasing concentration of tannins observed in the present study is in agreement with the earlier investigations (Kurosaki \& Nishi, 1983; Banso \& Adeyemo, 2007). The results of the present study support the traditional use of the Solanum trilobatum as green medicine. It also suggests that the tannins isolated from the test plant possess remarkable toxic activity against bacteria and may assume pharmacological importance.

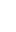

\begin{tabular}{|c|c|c|c|c|c|c|}
\hline \multirow{2}{*}{$\begin{array}{l}\text { Con. } \\
(\mathrm{mg} / \mathrm{ml})\end{array}$} & \multicolumn{6}{|c|}{ Mean diameter of zone of inhibition $(\mathrm{mm} \pm \mathrm{SD})$} \\
\hline & $\begin{array}{l}S . \\
\text { aureus }\end{array}$ & P.vulgaris & $\begin{array}{l}\text { P. aeru } \\
\text {-ginosa }\end{array}$ & S.typhi & $\begin{array}{l}S . \\
\text { pyrogens }\end{array}$ & E.coli \\
\hline 0.5 & $\begin{array}{l}8.3 \pm \\
0.28 \\
\end{array}$ & NA & NA & NA & NA & NA \\
\hline 1 & $\begin{array}{l}8.6 \pm \\
0.28\end{array}$ & $\begin{array}{l}7.8 \pm \\
0.280\end{array}$ & NA & $\begin{array}{l}8.5 \pm \\
0.5 \\
\end{array}$ & $9.6 \pm 0.28$ & NA \\
\hline 1.5 & $\begin{array}{c}10.5 \pm \\
0.5\end{array}$ & $\begin{array}{c}7.83 \pm \\
0.15\end{array}$ & $\begin{array}{c}8.0 \pm \\
0.5\end{array}$ & $\begin{array}{c}9.13 \pm \\
0.32\end{array}$ & $9.6 \pm 0.52$ & $\begin{array}{l}8.8 \pm \\
0.26 \\
\end{array}$ \\
\hline 2 & $\begin{array}{c}11.5 \pm \\
0.5\end{array}$ & $\begin{array}{c}8.83 \pm \\
0.28\end{array}$ & $\begin{array}{c}7.83 \pm \\
0.76 \\
\end{array}$ & $\begin{array}{c}10.5 \pm \\
0.5\end{array}$ & $10.5 \pm 0.5$ & $\begin{array}{l}8.8 \pm \\
0.35 \\
\end{array}$ \\
\hline 2.5 & $\begin{array}{c}13.5 \pm \\
0.5\end{array}$ & $\begin{array}{c}9.66 \pm \\
0.28\end{array}$ & $\begin{array}{c}8.73 \pm \\
0.25\end{array}$ & $\begin{array}{c}10.8 \pm \\
0.28\end{array}$ & $11.5 \pm 0.5$ & $\begin{array}{l}10.5 \pm \\
0.05\end{array}$ \\
\hline $\begin{array}{l}\text { Strepto } \\
\text {-mycin }\end{array}$ & 20 & 22 & 17 & 16 & 18 & 21 \\
\hline
\end{tabular}


4. Banso A and Adeyemo SO (2007) Evaluation of antibacterial properties of tannins isolated from Dichrostachys cinerea. Afr. J. Biotechnol. 6 (15), 1785-1787.

5. Bauer AW, Kirby WMM and Sherris JC (1966) Antibiotic susceptibility testing by a standardized single disk method. Am. J. Clin. Pathol. 45, 493496.

6. Bhagavathi A, Narayanana, Otto Geoffroya, Mark C Willinghama, Gian G. Reb, and Daniel W Nixona (1999) p53/p21 (WAFI/CIPI) expression and its possible role in G1 arrest and apoptosis in ellagic acid treated cancer cells. Cancer Letters. 136, 215221.

7. Collins GH, Lynes PM and Grange JM (1995) Microbiological Methods ( $7^{\text {th }}$ edn) Butterwort Heinemann Ltd, Britain. pp: 175-190.

8. Erasto P, Bojase-Moleta G and Majinda RRT (2004) Antimicrobial and antioxidant flavonoids from the roots wood of Bolusathus spesiosus. Phytochem. $65,875-880$.

9. Funatogawa K, Hayashi S, Shimomura H, Yoshida T, Hatano T, Ito H and Iría Y (2004) Antibacterial activity of hydrolysable tannins derived from medicinal plants against Helicobacter pylori. Microbiol. Immunol. 48 (4), 251-261.

10. Gajendiran N and Mahadevan A (1990) Utilization of catechin by Rhizobium sp. Plant Soil. 108, 263266.

11.Jawhar M, Amalan Rabert $G$ and Jeyaseelan $M$ (2004) Rapid proliferation of multiple shoots in Solanum trilobatum L. Plant Tissue Culture. 14 (2), 107-112.

12. Jigna Parekh and Sumitra Chanda (2007) Antibacterial and phytochemical studies on twelve species of Indian medicinal plants. Afr. J. Biotechnol. 10, 175-181.

13.Kurosoki F and Nishi A (1983) Isolation and antimicrobial activity of the phytoalexin-6methoxymellein from cultured carrot cells. Phytochemistry. 22 (3), 669-672.

14.Lin LU, Shu-wen L, Shi-bo J and Shu-guang W (2004) Tannin inhibits HIV-1 entry by targeting gp41. Acta Pharmacol Sin., 25 (2): 213-218.

15. Nair R and Chanda S (2005) Anticandidal activity of Punica granatum exhibited in different solvents. Pharm Biol. 43, 21-25.

16. Okogun JI (2000) Methods of Medicinal Plant extract preparation. National Institute for Pharmaceutical Research and Development (NIPRD) Idu - Abuja, Nigeria.

17.Perez C Paul $M$ and Bazerque $P$ (1990) An antibiotic assay by the agar-well diffusion method. Acta Biol. Med. Exp.15, 113-115.

18.Purushothaman KK, Saradambal $S$ and Narayanaswamy V (1969) Chemical estimation of
Solanum trilobatum.L. Aust.J.Chem. 22 (7), 15691570.

19.Salie F, Eagles PFK and Leng HMJ (1996) Preliminary antimicrobial screening of four South African Asteraceae species. J. Ethonopharmacol. 52, 27-33.

20.Shahjahan M, Sabitha KE, Mallika Devi R and Shyamala CS (2004) Effect of medicinal plants on tumurogenesis. Ind.J.Med.Res. 123 (5-8), 23- 27.

21.Shahjahan M, Vani G and Shyamaladevi CS (2005) Effect of Solanum trilobatum on the antioxidant status during diethyl nitrosamine induced and phenobarbital promoted hepatocarcinogenesis in rat. Chemico- Biological Interactions, 156 (2-3), 113-123.

22. Srinivasan D, Nathan $S$, Suresh T, Perumalsamy $O$ (2001) Antimicrobial activity of certain Indian medicinal plants used in folkloric medicine. $J$. Ethnopharmacol. 74, 217-220.

23. Tanimura S, Ryoji Kadomoto, Takashi Tanaka, Ying-Jun Zhang, Isao Kouno, and Michiaki Kohno (2005) Suppression of tumor cell invasiveness by hydrolyzable tannins (plant polyphenols) via the inhibition of matrix metalloproteinase-2/-9 activity. Biochem. Biophys. Res. Commun. 330, 13061313.

24. Trease GE and Evans IC (1983) Pharmacognosy (12th edn) Bailliere Tindall London. pp: 21-22.

25. Viljoen A, Van Vuuren S, Ernest E, Klepser M, Demirci B, Basser H and Van Wyk BE (2003) Osmitopsis asteriscoides (Asteraceae) - the antimicrobial and essential oil composition of cape - Dutch remedy. J. Ethnopharmacol. 88, 137-143.

26. Yang, Chih-Ying Lee and Kun-Ying Yen (2000) Induction of apoptosis by hydrolyzable tannins from Eugenia jambos L. on human leukemia cells. Cancer Letters. 157, 65-75.

27. Yao J, Moellering R (1995) Antibacterial agents. In: Manual of Clinical Microbiology, Murray $P$, Baron E,Pfaller M, Tenover F, Yolken R (Eds), ASM, Washington DC.1281-1290. 